ISSN: 1858-4837; E-ISSN: 2598-019X

Volume 15, Nomor 1 (2020),

https://jurnal.uns.ac.id/region

DOI: 10.20961/region.v15i1.23258

\title{
Efektivitas infrastruktur perkotaan dalam penanganan risiko banjir di Kota Surakarta
}

\author{
The effectiveness of city infrastucture for flood risk management in Surakarta
}

\author{
A A S Pramitha ${ }^{1}$, R Pamardhi-Utomo ${ }^{1}$, dan N Miladan ${ }^{1}$ \\ ${ }^{1}$ Program Studi Perencanaan Wilayah dan Kota, Fakultas Teknik, Universitas Sebelas \\ Maret
}

Corresponding author's email: arisekarp@gmail.com

\begin{abstract}
Abstrak. Kota Surakarta merupakan dataran rendah dengan ketinggian $\pm 92 \mathrm{~m}$ dari permukaan laut dan merupakan cekungan yang dikelilingi oleh pegununganpegunungan di Kabupaten Boyolali, Kabupaten Karanganyar, dan Kabupaten Sukoharjo. Selain itu, Kota Surakarta merupakan salah satu kota yang dilewati oleh sungai Bengawan Solo. Hal tersebut menyebabakan Kota Surakarta memiliki potensi untuk terjadinya bencana banjir. Maka dari itu, perlu adanya suatu manajemen risiko bencana banjir untuk mengurangi dampak yang dapat ditimbulkan dari bencana tersebut. Manajemen risiko banjir tersebut salah satunya adalah dengan mitigasi struktural berupa pembuatan sarana dan prasarana pengendali banjir dan pengadaan alat sistem peringatan dini. Penelitian ini berfokus kajian pada kajian tingkat efektivitas dari infrastruktur penanganan risiko bencana banjir. Tujuan dari penelitian ini adalah untuk mengaji efektivitas dari infrastruktur perkotaan dalam penanganan risiko banjir yang ada di Kota Surakarta. Metode yang digunakan adalah dengan deskriptif kuantitatif. Hasil dari penelitian ini menunjukkan bahwa tingkat efektivitas dari infrastruktur pengendali banjir di Kota Surakarta menunjukkan pada tingkat kurang efektif. Komponen infastruktur tanggul, bendung, dan sudetan sudah efektif menurunkan risiko kejadian (luasan, tinggi banjir, waktu kejadian) banjir dari tahun 2007 hingga tahun 2016. Namun, early warning system bencana banjir yang ada di Kota Surakarta menunjukkan pada hasil tidak efektif karena alat ini belum merata dan belum dapat menjangkau seluruh kawasan rawan banjir. Saat ini, banjir di Kota Surakarta sudah dapat dikendalikan, namun masih bermasalah dengan terjadinya genangan.
\end{abstract}

Kata Kunci: Banjir; Early Warning System; Efektivitas Infrastruktur; Manajemen Risiko; Mitigasi Bencana 


\begin{abstract}
Surakarta is a lowland with an altitude of \pm 92 meters above the sea level. It is a basin surrounded by mountains in Boyolali Regency, Karanganyar Regency, and Sukoharjo Regency. In addition, Surakarta is one of the cities passed by the Bengawan Solo river. This causes Surakarta to be potentially flooded. Therefore, it is necessary to have a flood disaster risk management to reduce the impact. The one of part of flood risk management is the structural mitigation in the form of making facilities and infrastructure for flood control and procurement of early warnig system tools. This study focuses on the level of effectiveness of infrastructure for flood risk management. The objective of this research is to review the effectiveness of city infrastructure for flood risk management in Surakarta. The method used is descriptive quantitative. The results of this study indicate that the level of effectiveness of flood control infrastructure in Surakarta shows at a less effective level. Infrastructure components such as dikes, weirs, and diversion has been effective in lowering the risk of flood incident (areas, flood height, time of occurance) 2007 until 2016. But, the early warning system for floods in Surakarta shows an ineffective because this tool is not evenly distributed and can't reach in all flood-prone areas. Currently, flooding in the city of Surakarta can be controlled, but still has problems with inundation.
\end{abstract}

Keywords: Disaster Mitigation; Early Warning System; Flood; Flood Risk Management; Infrastructure Effectiveness

\title{
1. Pendahuluan
}

Kota Surakarta merupakan salah satu kota yang berada di Provinsi Jawa Tengah. Kota ini merupakan dataran rendah dengan ketinggian $\pm 92 \mathrm{~m}$ dari permukaan laut dan merupakan cekungan yang di kelilingi oleh pegunungan-pegunungan di Kabupaten Boyolali, Kabupaten Karanganyar, dan Kabupaten Sukoharjo. Selain itu, Kota Surakarta merupakan salah satu kota yang dilewati oleh sungai Bengawan Solo.

Berdasarkan Pedoman Pengendalian Pemanfaatan Ruang di Kawasan Rawan Bencana Banjir, daerah rawan banjir adalah kawasan yang potensial untuk dilanda banjir yang diindikasikan dengan frekuensi terjadinya banjir (pernah atau berulang kali) [1]. Sebagai salah satu kota yang berada di daerah cekungan, Kota Surakarta sering menjadi langganan banjir. Banjir tersebut disebabkan oleh berbagai macam hal, seperti karena wilayah Kota Surakarta yang bersinggungan langsung dengan sungai Bengawan Solo, dataran yang mengalami banjir merupakan daerah padat penduduk, tingginya tingkat curah hujan yang turun, banjir kiriman dari daerah sekitar, serta kurang optimalnya penanganan banjir. Berdasarkan data yang telah didapatkan dari BPBD Kota Surakarta, terdapat beberapa kawasan banjir pada tahun 2016 di Kota Surakarta (Gambar 1).

Pada tahun 2016, di bagian Solo Utara adanya pola genangan yang terletak pada dataran rendah sepanjang Kali Pepe di Kelurahan Sumber, Nusukan, dan bantaran Kali Anyar yang disebabkan oleh elevasi yang rendah dan outlet saluran kurang baik. Pada daerah Solo Barat Daya, pola genangan terjadi pada pinggiran dan bantaran Kali Premulung di Kelurahan Sondakan, Pajang, Laweyan, Bumi, Panularan, Tipes, dan Joyotakan disebabkan oleh tambahan debit air sungai dari Kartasura. Sedangkan pada daerah Kali Pepe-Jenes dan 
antara tanggul lama-baru, pola genangan terletak di bekas Kali pepe-Jenes dan bantaran Sungan Bengawan Solo yaitu di Kelurahan Semanggi, Joyosuran, Pasar Kliwon, Sangkrah, Kedunglumbu, Gandekan, Sewu, Jagalan, Pucangsawit, dan Gilingan yang disebabkan oleh elevasi yang rendah, adanya pendangkalan, dan adanya backwater Sungai Bengawan Solo. Peta kawasan banjir di Kota Surakarta dapat dilihat pada Gambar 1.

Manajemen risiko bencana banjir adalah serangkaian kegiatan yang dilakukan pada saat sebelum terjadinya bencana atau pra-bencana [1]. Hal tersebut dilakukan untuk mengurangi dampak-dampak yang akan terjadi pada saat bencana banjir melanda. Tahapan ini meliputi pencegahan, kesiapsiagaan, dan mitigasi.

Salah satu cara mitigasi bencana dalam hal sarana dan prasarana pengendalian banjir menurut Putuhuru [1] adalah dengan pembangunan tembok penahan tanggul disepanjang sungai, tembok laut sepanjang pantai rawan badai atau tsunami untuk mengurangi bencana banjir pada tingkat debit air yang direncanakan. Pembangunan bangunan pengendalian banjir antara lain adalah tanggul, suur resapan, bendungan, waduk, polder, sudetan, kanal, kolam penampungan, dan pintu air [2]. Selain itu, sarana dan prasarana pertahanan dan pengendali banjir menurut Xiaotao \& Cheong [3] dapat berupa bendungan ataupun tanggul. Maka dari itu dapat diketahui bahwa sarana dan prasarana pengendali banjir adalah berupa tanggul, sudetan, bendung, serta pintu dan pompa air. Berdasarkan Pedoman Penyelenggaraan Kegiatan Operasi dan Pemeliharaan Prasarana Sungai serta Pemeliharaan Sungai, identifikasi efektivitas dari variabel ini dapat diketahui melalui tersedianya sarana dan prasarana pengendali banjir sesuai dengan fungsinya masing-masing [4]. Jika sudah terdapat sarana dan prasarana tersebut, serta sesuai dengan fungsinya masing-masing maka hal tersebut dapat dikatakan bahwa sarana dan prasarana tersebut sudah efektif. Efektivitasnya dinilai berhasil apabila memenuhi sasarannya yang ditinjau dari ketersediaan dan keberfungsian sarana prasarana tersebut. Ketersediaan dinilai apabila pada kawasan rawan banjir sudah memiliki infrastruktur pengendali banjir, sedangkan dikatakan berfungsi apabila infrastruktur tersebut dapat berfungsi sesuai dengan tujuannya yaitu untuk mengurangi risiko banjir.

Penyediaan sistem peringatan dini berupa alat pengirim dan penerima informasi juga tertera pada Materi teknis Pedoman Penyusunan Rencana Tata Ruang Berdasarkan Perspektif Pengurangan Risiko Bencana [2]. Infrastruktur ini merupakan teknologi pendeteksi datangnya bencana yang terdiri dari sirine dan lampu. Teknologi ini seharusnya dapat memberikan informasi tentang peringatan terjadinya bencana yang disampaikan dan dapat diterima oleh semua pihak. Informasi peringatan bencana berupa isyarat atau rambu, pesan, audio, dan visual [5]. Alat early warning system yang normal akan memberi tanda tentang kondisi Sungai Bengawan Solo secara berkala. Tanda tersebut diberikan melalui nyala lampu, apabila merah berarti kondisi siaga bencana banjir dan kuning berarti untuk kondisi waspada. Alat ini menjadi alat peringatan akan terjadinya banjir. Efektivitas dari alat early warning system diketahui melalui observasi langsung di lapangan pada wilayah yang rawan banjir dengan menilai ketersediaan dan keberfungsiannya. Menurut Sudarto [6], 
beberapa hal yang dapat dilakukan sebagai bentuk peringatan dini adalah pemasangan alat early warning system sesuai kapasitas dan lingkup bencana, pembuatan dan sosialisasi peta rawan bencana, serta upgrade prasarana dan data kebencanaan secara berkala.

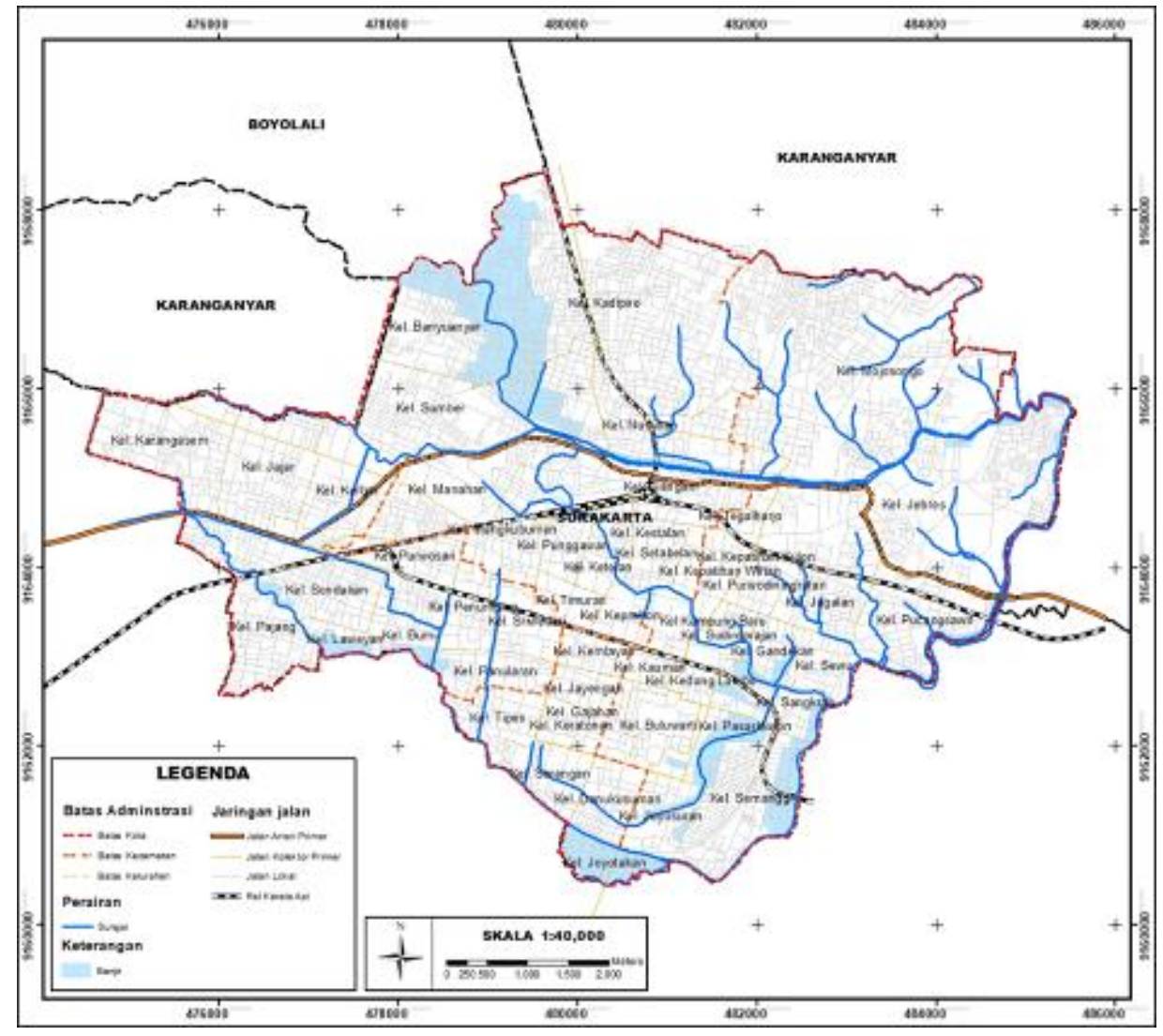

Gambar 1. Peta kawasan banjir Kota Surakarta 2016

Sejak tahun 2016, Pemerintah Kota Surakarta telah menggalakkan program normalisasi sungai dan renovasi Bendung Karet untuk mengurangi dampak banjir. Banjir tersebut sudah dapat dikendalikan mengingat luasan, tinggi banjir, dan lama dari kejadian banjir tersebut sudah berkurang dari banjir besar tahun 2007 silam. Meskipun sudah adanya penanganan secara struktural, namun tidak mengurangi kemungkinan adanya potensi banjir di Kota Surakarta.

Maka dari itu, perlu adanya penanganan risiko bencana dengan manajemen bencana yang dilakukan pada tahap pra-bencana. Manajemen risiko bencana yang efektif terutama pada infrastruktur sarana dan prasarana pengendali bencana banjir serta alat early warning system dilakukan untuk mengurangi dampak yang ditimbulkan banjir tersebut.

Mengacu pada permasalahan yang telah dijabarkan diatas, maka muncul pertanyaan penelitian bagaimanakah efektivitas infrastruktur perkotaan dalam menangani risiko banjir di Kota Surakarta. Penelitian ini memberikan kebaharuan substansi riset karena penelitianpenelitian sebelumnya hanya membahas mengenai manajemen bencana banjir melalui 
pendekatan kelembagaan pemerintahan (SATLAK PBP, BPBD, maupun masyarakat), sedangkan tujuan dari penelitian ini adalah untuk mengetahui efektivitas dari infrastruktur perkotaan dalam penanganan risiko banjir di Kota Surakarta.

\section{Metode}

Pendekatan yang digunakan dalam penelitian ini adalah pendekatan deduktif dengan jenis penelitian kuantitatif. Proses pengumpulan data dilakukan dengan survei primer dengan observasi lapangan secara langsung guna mengetahui kejadian yang ada di lapangan serta dengan malakukan wawancara kepada stakeholder yang memiliki ahli dan atau pengalaman dalam bidang infrastruktur penanganan banjir berupa tanggul, bendung, sudetan, pintu dan pompa air, serta early warning system. Data yang telah didapat kemudian dianalisis dengan teknik analisis deskriptif kuantitatif untuk mengetahui ketersediaan dan keberfungsian dari infrastruktur tersebut. Kemudian dilakukan teknik analisis skoring guna mengetahui efektivitas dari infrastruktur perkotaan penanganan banjir tersebut.

Metode skoring ini memberikan bobot/nilai yang sama karena setiap variabel dianggap sama pentingnya. Jumlah nilai dalam parameter efektif yaitu 3 , kurang efektif yaitu 2 , dan tidak efektif yaitu 1. Kemudian dilakukan penilaian dari setiap infrastruktur penelitian yaitu efektivitas dari tanggul, bendung, sudetan, serta pintu dan pompa air, early warning system pada setiap tingkat kerawanan banjir yaitu sangat tinggi, tinggi, sedang, dan rendah. Dasar penilaian skoring setiap infrastruktur pada tiap tingkat kerawanan dapat dilihat pada Tabel 1.

Tabel 1. Skoring pada setiap infrastruktur pada tingkat kerawanan

\begin{tabular}{lccccc}
\hline \multirow{2}{*}{ Infrastruktur } & \multicolumn{4}{c}{ Tingkat Kerawanan } & $\begin{array}{c}\text { Tingkat } \\
\text { Efektivitas }\end{array}$ \\
\cline { 2 - 5 } & Sangat Tinggi & Tinggi & Sedang & Rendah & $1 / 2 / 3$ \\
\hline Tanggul & $1 / 2 / 3$ & $1 / 2 / 3$ & $1 / 2 / 3$ & $1 / 2 / 3$ & $1 / 3$ \\
Bendung & $1 / 2 / 3$ & $1 / 2 / 3$ & $1 / 2 / 3$ & $1 / 2 / 3$ & $1 / 2 / 3$ \\
Sudetan & $1 / 2 / 3$ & $1 / 2 / 3$ & $1 / 2 / 3$ & $1 / 2 / 3$ & $1 / 2 / 3$ \\
Pintu dan Pompa air & $1 / 2 / 3$ & $1 / 2 / 3$ & $1 / 2 / 3$ & $1 / 2 / 3$ & $1 / 2 / 3$ \\
Early Warning System & $1 / 2 / 3$ & $1 / 2 / 3$ & $1 / 2 / 3$ & $1 / 2 / 3$ & $1 / 2 / 3$ \\
\hline
\end{tabular}

$$
\text { Interval }=\frac{\text { nilai maksimal }- \text { nilai minimal }}{\text { jumlah interval }}=\frac{12-4}{3}=2,67
$$

Maka, nilai interval per infrastruktur variabel dikatakan:

$\begin{array}{ll}\text { Efektif (3) } & \rightarrow \text { jika nilai antara 9,33-12 } \\ \text { Kurang efektif (2) } & \rightarrow \text { jika nilai antara } 6,65-9,32 \\ \text { Tidak efektif (1) } & \rightarrow \text { jika nilai antara } 4-6,64\end{array}$




$$
\text { Semua infrastruktur: Interval }=\frac{\text { nilai maksimal-nilai minimal }}{\text { jumlah interval }}=\frac{6-2}{3}=1.3
$$

Keterangan:

Efektif (3) $\rightarrow$ jika nilai antara $4.7-6$

Kurang efektif (2) $\rightarrow$ jika nilai antara $3.4-4.6$

Tidak efektif (1) $\rightarrow$ jika nilai antara $2-3.3$

Alur proses penelitian dapat dilihat pada Gambar 2.

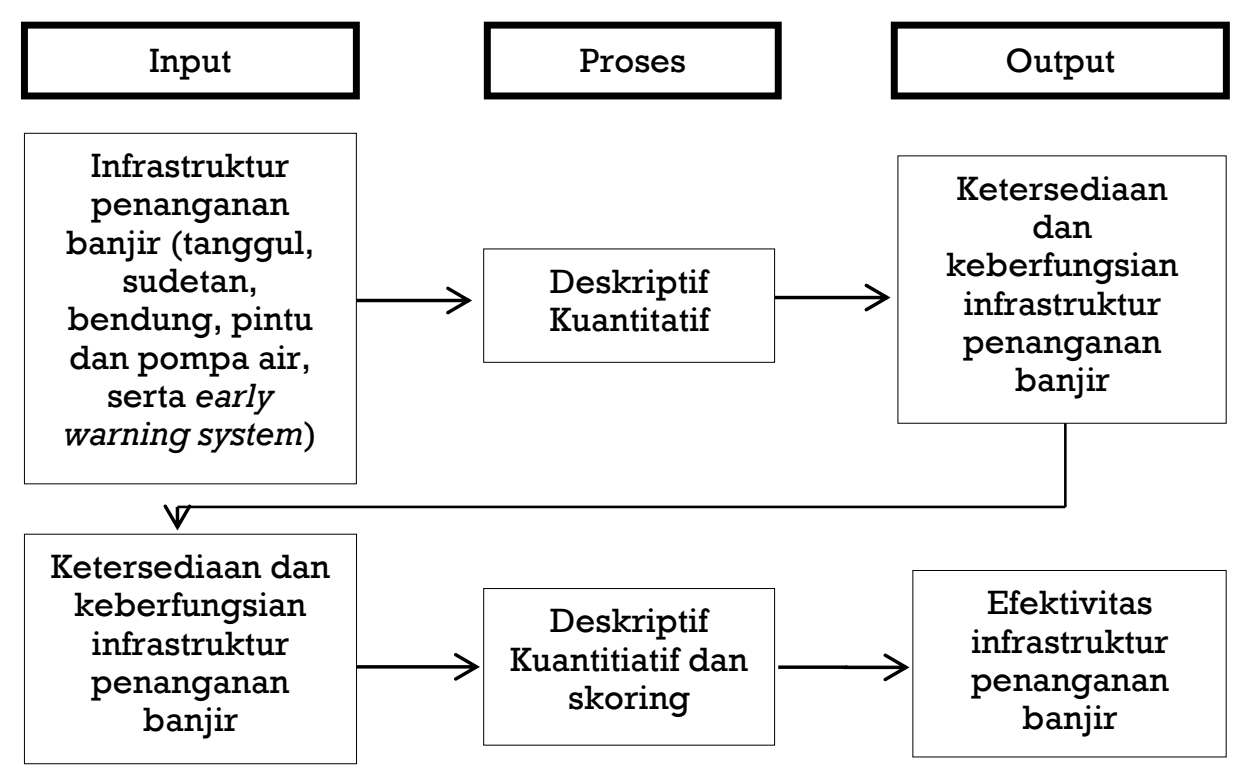

Gambar 2. Kerangka analisis penelitian

\section{Hasil penelitian dan pembahasan}

\subsection{Gambaran infrastruktur penanganan banjir}

Infrastruktur tersebut diantaranya adalah tanggul, bendung, sudetan, serta pintu dan pompa air. Untuk mengetahui efektivitasnya, peneliti membandingkan dengan kejadian banjir pada tahun 2007 yang merupakan banjir terbesar di Kota Surakarta dengan kejadian banjir 2016. Hal tersebut dikarenakan pembatasan waktu oleh peneliti serta adanya perubahan paradigma baru pada pemerintah dalam penanganan banjir. Perbandingan luas kejadian banjir 2007 dengan 2016 Kota Surakarta dapat dilihat pada Tabel 2.

Tabel 2. Perbandingan luas kejadian banjir 2007 dengan 2016 Kota Surakarta [7].

\begin{tabular}{lcccccc}
\hline \multirow{2}{*}{ Bagian Wilayah } & \multicolumn{2}{c}{ Luas $(\mathrm{Ha})$} & \multicolumn{2}{c}{ Tinggi $(\mathrm{m})$} & \multicolumn{2}{c}{ Lama Kejadian (jam) } \\
\cline { 2 - 7 } & 2007 & 2016 & 2007 & 2016 & 2007 & 2016 \\
\hline 1. Solo utara & 116,05 & 167,35 & $0,5-1$ & $0,3-2$ & 12 & $6-12$ \\
2. Solo barat daya & 42,85 & 4,73 & 1 & $1-1,2$ & $12-24$ & $3-6$ \\
3. Solo timur-selatan & 228,37 & 5,94 & $0,5-2,5$ & $0,8-1,7$ & $12-72$ & $3-48$ \\
4. Solo timur laut & 425,13 & 67.62 & $0,5-3$ & $0,5-3$ & $12-96$ & $4-48$ \\
$\quad$ TOTAL & $\mathbf{8 1 2 , 4}$ & $\mathbf{2 4 5 , 6 4}$ & $\mathbf{0 , 5 - 3}$ & $\mathbf{0 , 3 - 3}$ & $\mathbf{1 2 - 7 2}$ & $\mathbf{3 - 4 8}$ \\
\hline
\end{tabular}


Data tersebut merupakan data luasan kawasan banjir, tinggi, dan lama kejadian banjir yang terjadi pada tahun 2007 sebelum dilakukan pembenahan dan kejadian banjir pada tahun 2016 setelah dilakukannya pembenahan infrastruktur penanganan banjir oleh pemerintah Kota Surakarta.

Dalam penanganannya banjir, Pemerintah Kota Surakarta telah melakukan beberapa tindakan untuk mengurangi risiko banjir yang dialami. Setelah banjir besar yang terjadi pada tahun 2007, pemerintah mulai melakukan pembenahan pada infrastruktur manajemen risiko bencana banjir sehingga dapat mengurangi risiko banjir pada tahun berikutnya yaitu 2016. Penanganan setelah banjir 2007 tersebut adalah dengan dilakukannya peninggian tanggul, perbaikan pintu dan pompa air, serta normalisasai sugai untuk mengurangi dampak dari bencana banjir yang mungkin akan terjadi berikutnya. Untuk mempermudah penelitian ini dibagi dalam 3 kawasan penelitian yaitu 1. Solo Utara, 2. Solo Barat Daya, 3. Solo TimurSelatan, dan 4. Solo Timur Laut. Untuk lebih jelasnya dapat dilihat pada Gambar 3.

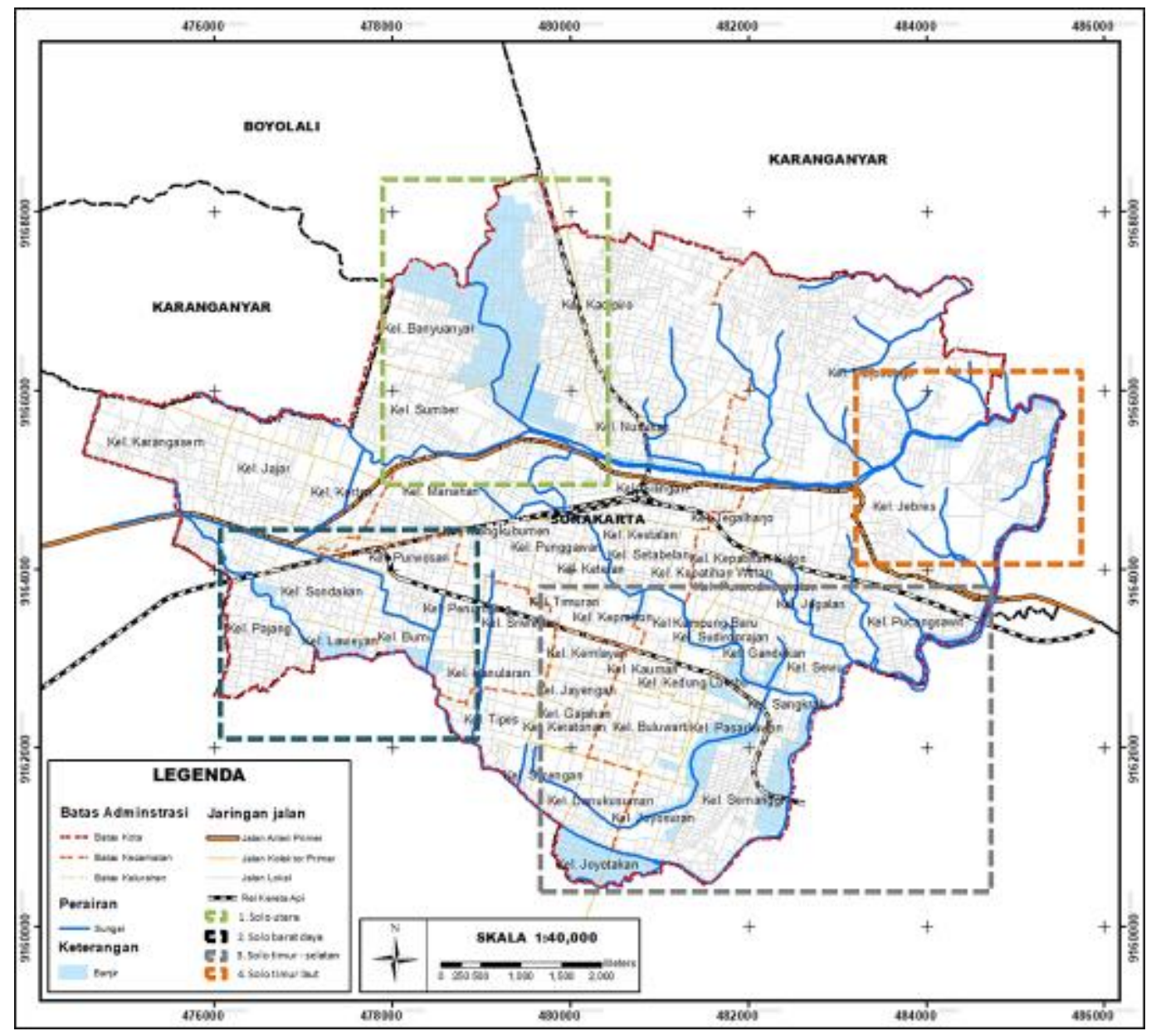

Gambar 3. Peta pembagian kawasan

3.1.1 Tanggul. Dari wawancara yang telah dilakukan dengan bapak Sihono selaku Kepala Seksi Pembangunan Sumber Daya Air Dinas PU Kota Surakarta 2018, diketahui bahwa 
mayoritas kondisi tanggul sudah baik dan berfungsi dengan optimal. Namun, ada di beberapa titik yang rusak dan saat ini dilakukan penanganan yaitu di Tipes hingga Joyosuran. Penyebab dari kerusakan tanggul ini biasanya merupakan ulah tangan manusia. Banyak masyarakat yang menguruk tanah tanggul lalu dijadikan bagian dari rumahnya. Selain itu, di daerah Sangkrah dan Sewu, tanggul sempat merembeskan air dari Bengawan Solo namun saat ini telah dilakukan penanganan dengan dibangun parapet di daerah Sungai Bengawan Solo untuk menangani banjir dan mengurangi rembesan air tersebut [8].

Ditinjau dari ketersediaannya, tanggul tersebar di sungai-sungai utama yang menjadi prioritas penanganan yang ada di Kota Surakarta seperti disepanjang Bengawan Solo, sebagian disepanjang Kali Pepe, sebagian disepanjang Kali Gajah Putih, dan sebagian disepanjang Kali Anyar. Informasi ini dapat dilihat pada Gambar 4. Tidak semua sungai yang ada di Kota Surakarta diberi tanggul karena melihat dari tingkat urgensiya seperti pada Kali Anyar yang memang sengaja tidak diberi tanggul karena Kali Anyar memiliki palung yang cukup dalam. Pada Kali Pepe bagian utara belum dibangun tanggul, maka pada setiap terjadi hujan lebat air selalu melimpas ke wilayah sekitar sungai. Banjir di Solo bagian utara ini biasa disebabkan oleh banjir kiriman dari sungai-sungai yang ada di Boyolali. Selain itu juga disebabkan oleh ulah manusia yang membangun rumah sangat berdekatan dengan sungai dengan jarak 2 meter dari sungai.

Keberfungsian tanggul ditinjau dari daerah yang terkena banjir pada tahun 2007 dan 2016. Dari gambar 3 dapat diketahui keberfungsian dari tanggul yang ada di Kota Surakarta pada tahun terakhir yaitu 2017 adalah sudah efektif karena tanggul tersebut sudah dapat mengurangi risiko banjir yang ada di Kota Surakarta dari tahun 2007 hingga 2016. Hal tersebut dilakukan Balai Besar Bengawan Solo dengan meninggikan tembok tanggul (parapet) setelah adanya kejadian banjir besar tahun 2007 tersebut hingga mencapai tampungan air $Q 50$ tahun atau sebanyak $1331,86 \mathrm{~m}^{3} /$ detik dari sebelumnya yang hanya $Q$ 25 tahun atau sebanyak 1209,11 $\mathrm{m}^{3}$ /detik. Peninggian tembok tersebut dilakukan di sekitar Sungai Bengawan Solo. 


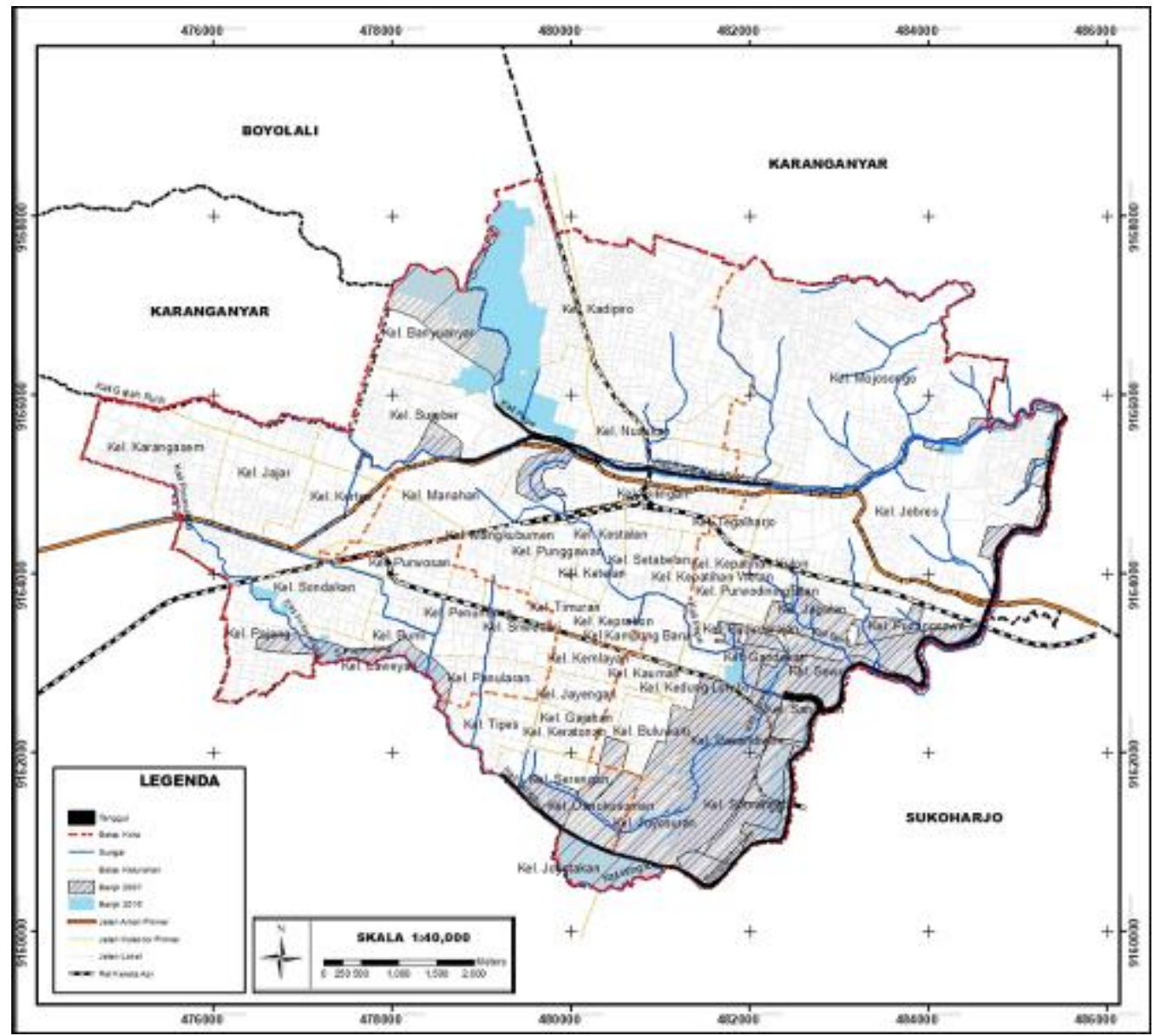

Gambar 4. Peta tanggul Kota Surakarta [9]

3.1.2 Bendung. Bendung Karet Tirtonadi belum sepenuhnya selesai maka sekarang sedang dalam masa uji coba. Dalam masa percobaan ini pada saat terjadi hujan lebat, tinggi permukaan air di Bendung Karet Tirtonadi ini tidak mencapai level yang berbahaya. Karena pada musim hujan, kapasitas pengaliran air sebesar $1.048 \mathrm{~m} 3$ dan hal ini merupakan nilai dari segi keberfungsian karena hal ini menunjukkan kapasitas air yang lebih dari debit awal yaitu 390 m3. Sehingga dapat disimpulkan pada tahap uji coba, Bendung Karet Tirtonadi ini berhasil mencapai fungsinya hingga air sungai Kali Pepe dapat terbendung dengan baik dan tidak meluber hingga menyebabkan banjir di wilayah sekitarnya. Bendung ini digunakan untuk mencegah banjir khususnya di daerah utara Kota Surakarta. Untuk lebih jelasnya, berikut peta letak Bendung Karet Tirtonadi dapat dilihat pada Gambar 5.

3.1.3 Sudetan. Sudetan yang paling berpengaruh dalam pengendalian banjir di Kota Surakarta adalah sudetan Kali Pepe yang sekarang diberi nama Kali Anyar. Dengan adanya sudetan ini, diketahui bahwa sudah mengurangi kejadian banjir di Kota Surakarta bila dibandingkan dengan tahun sebelumya. Sudetan tersebut sudah dapat mengalihkan air dari Kali Pepe yang langsung mengarah ke dalam Kota Surakarta dan dialihkan langsung ke Bengawan Solo. Sudetan ini sudah dapat berfungsi sesuai dengan tujuannya karena sudah dapat mengurangi dan tidak menimbulkan banjir didalam Kota Surakarta. 
Ketersediaan dan keberfungsian sudetan ini dapat dikatakan sudah efektif karena sudah dapat meniadakan banjir terutama di dalam (di pusat) Kota Surakarta pada kejadian banjir terakhir yaitu tahun 2016. Untuk lebih jelasnya dapat dilihat pada Gambar 6.

2.1.1 Pintu dan pompa air. Pintu air dan pompa air yang ada di Kota Surakarta sudah menyebar pada titik-titik tertentu. Keberfungsiannya dapat dilihat dari berkurangnya kawasan banjir dari banjir tahun 2007 dengan 2016. Pintu air dan pompa air berpegaruh pada banjir tahun 2007 karena pada tahun tersebut rata-rata pintu dan pompa air mengalami kerusakan dibagian ulir maupun daun pintu sehingga saat banjir terjadi tidak dapat difungsikan sebagaimana mestinya. Setelah banjir dahsyat tersebut, dilakukn perbaikan pintu dan pompa air oleh Pemerintah Kota Surakarta sehingga pada kejadian banjir berikutnya yaitu tahun 2016, banjir dapat dikendalikan dan dikurangi luasannya. Maka dari itu, efektivitas sarana dan prasarana pintu dan pompa air di kawasan banjir termasuk dalam kategori efektif. Gambar 7 merupakan peta persebaran pintu dan pompa air di Kota Surakarta.

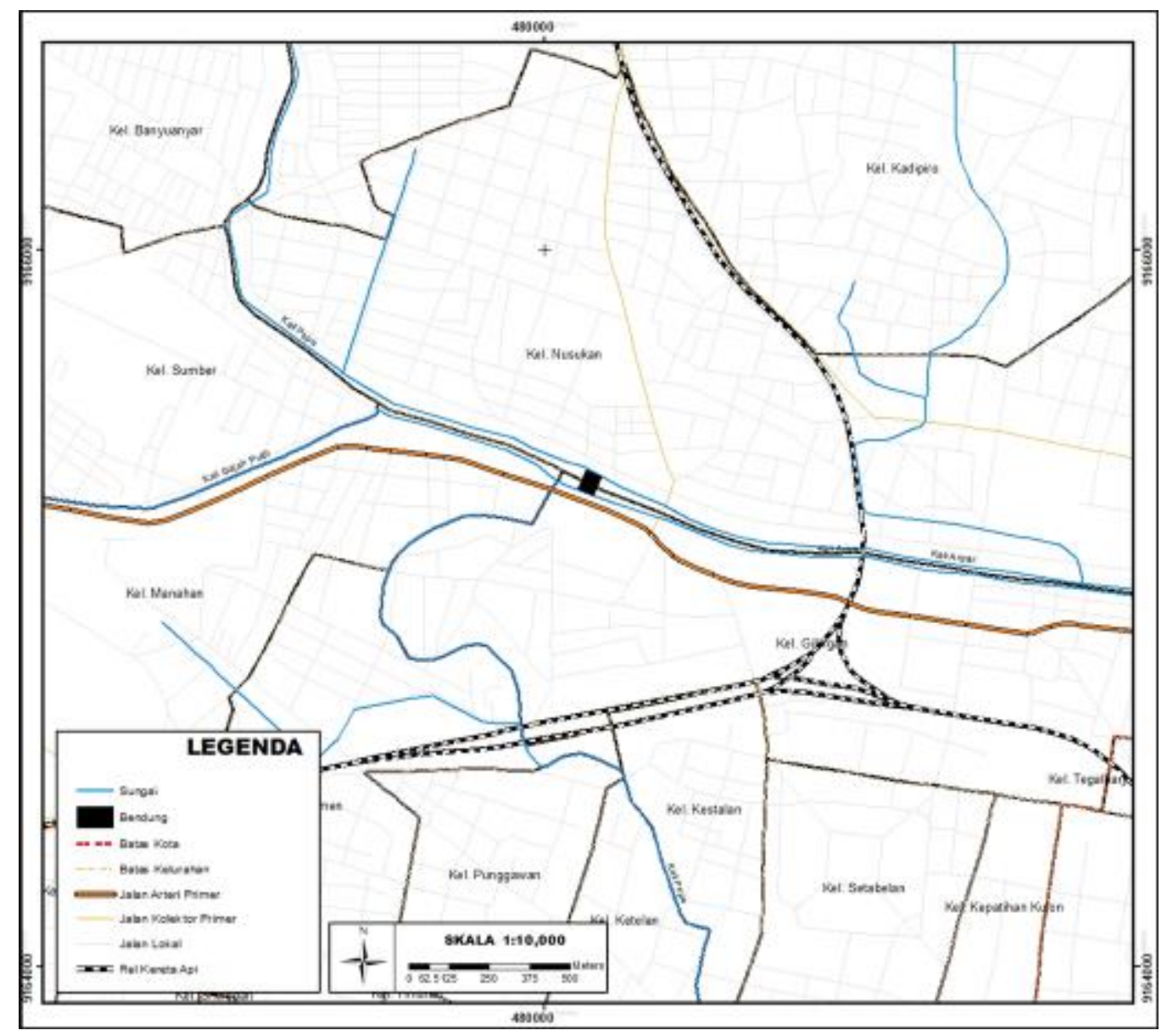

Gambar 5. Peta Bendung Karet Tirtonadi [10] 


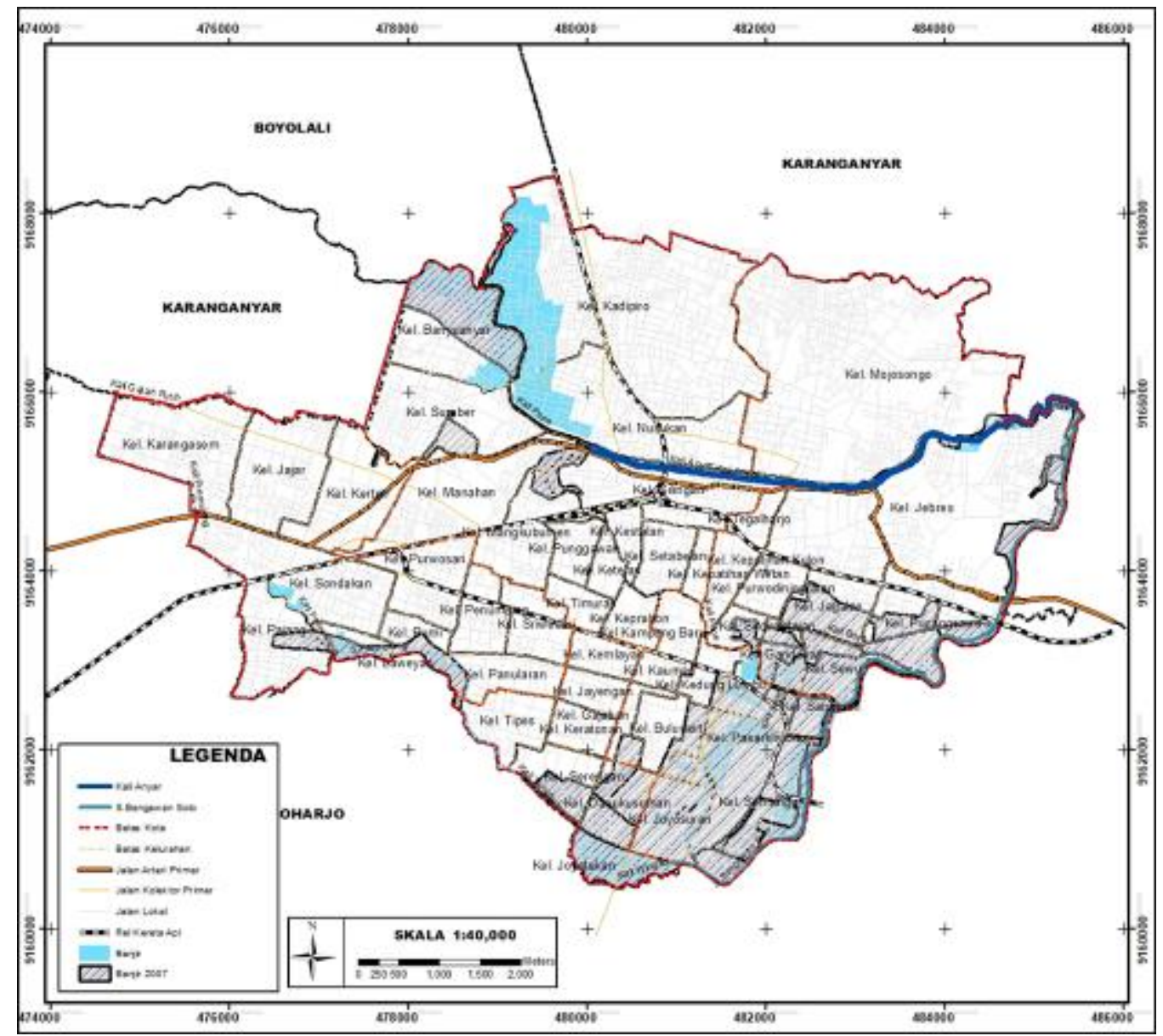

Gambar 6. Peta sudetan (Kali Anyar) Kota Surakarta [11].

Infrastruktur-infrastruktur tersebut berfungsi sesuai dengan tujuannya masing-masing karena sudah dapat mengurangi kejadian banjir yang ada di Kota Surakarta. Hal tersebut dapat dibuktikan dengan berkurangnya luasan, tinggi banjir, dan lama kejadian banjir pada daerah banjir yang terjadi antara tahun 2007 dengan 2016. Dari data dan analisis yang telah dilakukan, dapat diketahui bahwa dengan adanya pembenahan inftrastruktur penanganan banjir tersebut dapat meminimalisir risiko banjir yang yang akan datang. Hal tersebut dibuktikan dengan berkurangnya luasan banjir yang terjadi pada tahun 2016. Setelah sebelumnya yaitu pada tahun 2007 Kota Surakarta tergenang banjir seluas 812,4 ha, setelah dilakukannya penanganan tersebut banjir pada tahun 2016 berkurang sebanyak 80,04\% atau menjadi 245,64 ha. Waktu terjadinya banjir juga mengalami penurunana, pada tahun 2007 rata-rata kejadian banjir berlangsung selama 12-72 jam, namun setelah dilakukannya pembenahan banjir berkurang menjadi 3-42 jam pada kejadian banjir 2016. Namun demikian, untuk ketinggian banjirnya, tidak jauh berbeda dari tahun 2007. Berkurang sekitar 0,2 m dari kejadian banjir pada tahun 2007 namun, paling tinggi memiliki ketinggian sekitar $3 \mathrm{~m}$. 


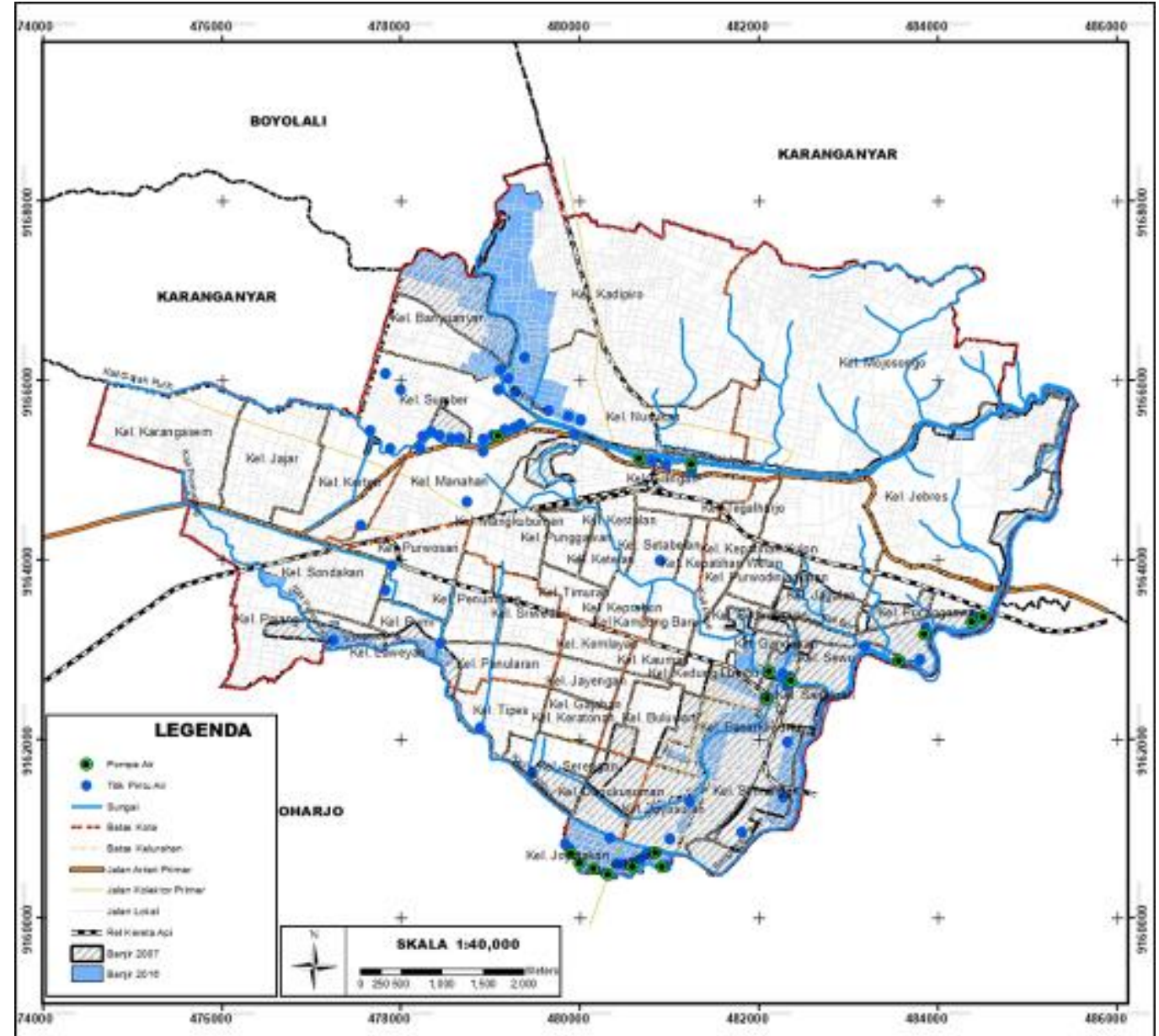

Gambar 7. Peta persebaran pintu dan pompa air di Kota Surakarta [12]

\subsection{Early warning system}

Early warning system di Kota Surakarta hanya terdapat pada kawasan rawan banjir dengan tingkat kerawanan tinggi dan sangat tinggi. Sedangkan pada kawasan dengan tingkat kerawanan rendah dan sedang belum memiliki alat ini sebagai alat sistem peringatan dini. Lampu isyarat yang digunakan biasanya sudah menjadi satu dengan alat early warning system yang telah dipasang. Alat early warning system ini dapat dijangkauan hingga sejauh 5 $\mathrm{km}$ dan masih dapat berfungsi dengan baik. Apabila tinggi muka air sungai sudah mencapai darurat, sirine dan lampu akan otomatis berbunyi. Namun, dilihat dari jangkauannya, alat ini belum menjangkau seluruh kawasan rawan banjir. Gambar 8 merupakan peta jangkauan dari alat early warning system yang ada di Kota Surakarta. 


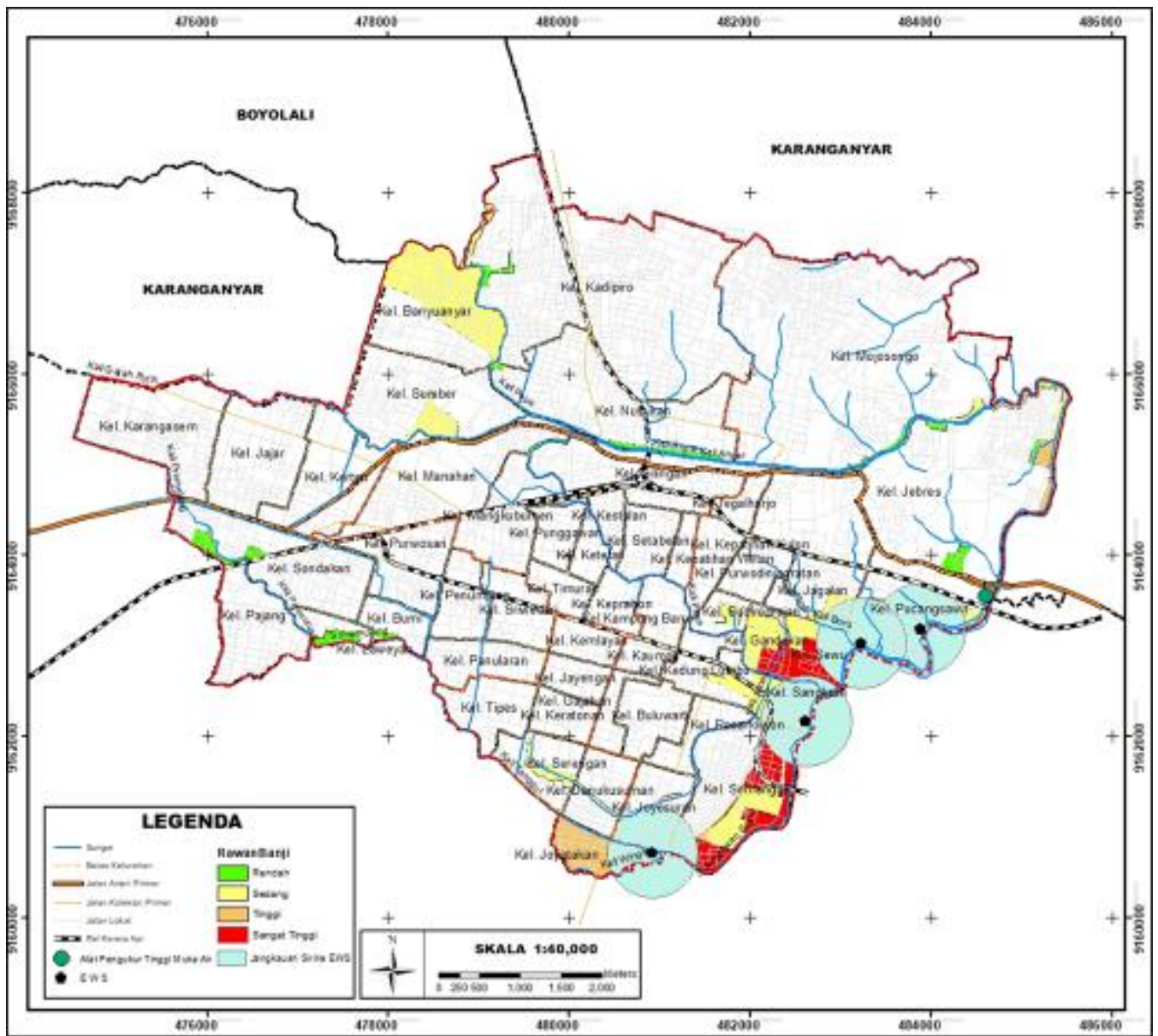

Gambar 8. Peta early warning system di Kota Surakarta

Setelah dilakukan observasi lapangan, didapatkan bahwa masyarakat tidak hanya mengandalkan alat early warning system ini apabila ada tanda-tanda akan terjadinya banjir. Masyarakat yang tinggal pada kawasan sepanjang sungai yang memiliki tingkat kerawanan pada bencana banjir juga memanfaatkan kentongan dan alat pengeras suara masjid untuk memberi peringatan. Selain itu, pada warga sempadan sungai ada pula yang hanya dengan memerhatikan tanda-tanda alam yaitu dengan pengamatan tinggi air sungai secara langsung. Di Kota Surakarta, selain memiliki alat early warning system juga memiliki pos dan alat tinggi muka air. Alat ini memiliki semacam server yang dapat secara langsung mencatat data tinggi muka air sungai Bengawan Solo setiap jamnya lalu mengirimkannya ke pihak BBWS Bengawan Solo.

\subsection{Tingkat efektivitas infrastruktur perkotaan pengendali banjir di Kota Surakarta}

Dengan demikian, dapat disimpulkan bahwa tingkat efektivitas infrastruktur manajemen risiko bencana banjir di Kota Surakarta menurut tingkat kerawanannya adalah sebagai berikut. 
Tabel 3. Efektivitas infrastruktur

\begin{tabular}{|c|c|c|c|c|c|c|}
\hline \multirow[t]{2}{*}{ Infrastruktur } & \multicolumn{4}{|c|}{ Tingkat Kerawanan } & \multirow[t]{2}{*}{ Nilai } & \multirow{2}{*}{$\begin{array}{c}\text { Tingkat } \\
\text { Efektivitas }\end{array}$} \\
\hline & Rendah & Sedang & Tinggi & $\begin{array}{c}\text { Sangat } \\
\text { Tinggi }\end{array}$ & & \\
\hline Tanggul & \multicolumn{4}{|c|}{ Efektif (3) } & 12 & Efektif (3) \\
\hline Bendung & \multicolumn{4}{|c|}{ Efektif (3) } & & \\
\hline Sudetan & \multirow{2}{*}{\multicolumn{4}{|c|}{ Efektif (3) }} & & \\
\hline Pintu dan Pompa air & & & & & & \\
\hline Early Warning System & $\begin{array}{c}\text { Tidak } \\
\text { efektif (1) }\end{array}$ & $\begin{array}{c}\text { Tidak } \\
\text { efektif (1) }\end{array}$ & $\begin{array}{l}\text { Kurang } \\
\text { Efektif } \\
\text { (2) }\end{array}$ & $\begin{array}{c}\text { Kurang } \\
\text { Efektif (2) }\end{array}$ & 6 & $\begin{array}{l}\text { Tidak efektif } \\
\text { (1) }\end{array}$ \\
\hline
\end{tabular}

Dari Tabel 3 diketahui bahwa 4 infrastruktur penanganan banjir yaitu tanggul, bendung, sudetan, pintu dan pompa air di Kota Surakarta adalah sudah efektif. Namun demikian, pada alat early warning system sebagai alat pendeteksi terjadinya banjir adalah tidak efektif. Maka dari itu, dapat diketahui dengan rumus interval yang telah ditetapkan bahwa efektivitas dari infrastruktur-infrastruktur tersebut adalah kurang efektif karena memiliki nilai 4. Hal tersebut dikatakan kurang efektif karena dalam penanganannya infrastruktur penanganan banjir seperti tanggul, bendung, sudetan, dan pintu air serta pompa air sudah dapat mengendalikan banjir, dibuktikan dengan berkurangnya luasan, tinggi genangan banjir, dan lama kejadian banjir yang terjadi pada tahun 2007 dan 2016. Pada tahun 2017, banjir sudah tidak terjadi lagi di Kota Surakarta, hanya teradapat masalah genangan yang tidak menyebabkan banjir yang terjadi akibat kurang berfungsinya drainase tersier di permukiman masyarakat. Sedangkan alat early warning system tidak efektif karena alat ini tidak menjangkau seluruh kawasan rawan banjir.

\section{Kesimpulan}

Efektivitas dari infrastruktur penanganan banjir di Kota Surakarta termasuk dalam kategori kurang efektif. Hal tersebut dikarenakan ketersediaan dan keberfungsian dari tanggul, bendung, sudetan, serta pintu dan pompa air yang ada di Kota Surakarta sudah dapat mengurangi luas wilayah dan waktu kejadian banjir yang terjadi pada tahun 2007 dan banjir tahun 2016. Dari luas wilayah yang terkena banjir 812,4 ha pada tahun 2007 menjadi 245,64 ha pada tahun 2016 setelah adanya perbaikan dan pembenahan infrastruktur yang dilakukan pemerintah Kota Surakarata. Meskipun dari segi ketinggian banjirnya masih tetap sama yaitu mencapai 0,5-3 meter. Namun demikian, meskipun banjir sudah tidak terjadi karena sudah tepat dan efektifnya penanganan dalam pengendalian banjir di Kota Surakarta, masih terjadi beberapa masalah di tengah perkotaan Kota Surakarta yaitu berupa genangan. Genangan ini biasa disebabkan oleh meluapnya air dari saluran drainase tersier yang mendangkal ataupun tersumbat oleh sampah. Sedangkan, pada efektivitas early warning system termasuk dalam kategori tidak efektif. Hal tersebut dikarenakan belum semua kawasan rawan bajir tersedia alat early warning system. Alat tersebut hanya ada di empat titik pada kawasan rawan banjir tinggi dan sangat tinggi. Meskipun alat tersebut dapat berfungsi secara normal, namun alat-alat yang sudah ada tersebut belum menjangkau seluruh kawasan rawan tinggi maupun sangat tinggi banjir. Dalam penanganan banjir, 
pemerintah memiliki prioritas pembangunan tersendiri yang ditinjau dari berbagai macam aspek. Oleh sebab itu, masih terdapat beberapa infrastruktur yang belum tersedia di kawasan rawan banjir guna penanganan bencana banjir di Kota Surakarta.

\section{Referensi}

[1] Putuhuru F 2015 Mitigasi Bencana dan Penginderaan Jauh (Yogyakarta: Graha Ilmu)

[2] Bappenas 2014 Materi Teknis Penyusunan Rencana Tata Ruang Berdasarkan Perspektif Pengurangan Risiko Bencana (Jakarta: Badan Perencanaan Pembangunan Nasional)

[3] Xiaotao C, dan Cheong T S 2013 Guidelines On Urban Flood Risk Management (UFRM). Diakses http://www.typhooncommittee.org/45th/Docs/item\%207/TOD of the Guidelines on UFRM-2013.pdf pada 30-10-2017

[4] Kementerian Pekerjaan Umum dan Perumahan Rakyat 2016 Pedoman Penyelenggaraan Kegiatan Operasi dan Pemeliharaan Prasarana Sungai Serta Pemeliharaan Sungai Diakses dari http://sda.pu.go.id/uploads/file/SE Dirjen SDA Penyelenggaraan-Kegiatan-OPPrasarana-Sungai.pdf pada 06-01-2020

[5] International Federation of Red Cross and Red Crescent Societies 2013 Community Early Warning System: Guiding Principles Diakses dari https://www.ifrc.org/PageFiles/103323/1227800-IFRC-CEWS-Guiding-PrinciplesEN.pdf pada 06-01-2020

[6] Sudarto G 2007 Kebijakan PEMDA Bantul tentang Mitigasi Bencana Pelatihan Mitigasi Bencana Bagi Aparatur Pemerintah Kabupaten Bantul

[7] Dinas Pekerjaan Umum Kota Surakarta 2018 Data Perbandingan luas kejadian banjir 2007 dengan 2016 Kota Surakarta

[8] Sihono 2018 Komunikasi personal

[9] Badan Perencanaan Pembangunan Daerah Kota Surakarta 2018 Peta Tanggul Kota Surakarta

[10] Dinas Pekerjaan Umum Kota Surakarta 2018 Peta Bendung Karet Tirtonadi

[11] Dinas Pekerjaan Umum Kota Surakarta 2018 Peta sudetan (Kali Anyar) Kota Surakarta

[12] Dinas Pekerjaan Umum Kota Surakarta 2018 Peta persebaran pintu dan pompa air di Kota Surakarta 